\title{
Theologie: Een dwaze wetenschap? ${ }^{1}$
}

\begin{abstract}
In the Netherlands, theology is currently disappearing from the non-confessional universities. That is to be deplored, since theology has several important public functions. One of these is that theology contributes to the 'normative capital' of a society. But is theology up to its public functions? Or has it become a pastime for an in-crowd that is irrelevant for the wider society? The argument proceeds in two stages. First: Can one adhere to the maxim Lex orandi, lex credendi without giving up one's intellectual autonomy and becoming irrelevant to non-believers? By explaining this maxim in light of its origin with Prosper of Aquitaine, the author shows that this is indeed possible. Second: Is there something to be learnt from Erasmus of Rotterdam, who - while being a confessional theologian - has become an icon of modernity? The author argues on the basis of his Enchiridion and his Praise of Folly that Erasmus was a constructive theologian with serious attention for the spiritual life. We can learn from him (1) to uphold the highest academic standards, (2) to combine loyalty to confession with a critical attitude towards abuses, (3) to denounce abuses without attacking individuals, and (4) to root our theologies in the piety of a community.
\end{abstract}

\section{DE PUBLIEKE FUNCTIE VAN CONFESSIONELE THEOLOGIE}

De organisatie van het theologisch onderwijs en onderzoek in Nederland maakt turbulente ontwikkelingen door. Eén van die ontwikkelingen is de onttakeling van de theologie aan de openbare universiteiten. De afgelopen vijfentwintig jaar heb ik als theoloog gewerkt aan een openbare universiteit, de Universiteit Utrecht. Toen ik begon te werken, was dat nog aan een Faculteit Godgeleerdheid; toen ik enkele dagen geleden de deur achter mij dichttrok, was dat de deur van een Departement Religiewetenschap en Theologie, een Departement dat bezig is de theologie te ontmantelen en op te gaan in een Departement Wijsbegeerte en Religiewetenschap. De ontwikkelingen aan de Universiteit Utrecht staan niet op zichzelf; ook aan de Universiteit van Amsterdam is de theologie verdwenen en aan de Universiteit van Leiden leidt zij een kwijnend bestaan. De Rijksuniversiteit Groningen lijkt als enige openbare universiteit nog bereid om in de theologie te investeren.

De teloorgang van de theologie aan openbare universiteiten is een gevolg van een dalend studentenaanbod in combinatie met onvoldoende inzicht in het belang van theologie. Het dalend studentenaanbod leidt ertoe dat het aanbieden van theologie voor openbare universiteiten financieel onaantrekkelijk is. Dan ga je daar alleen mee door als je er op inhoudelijke gronden belang aan hecht. De praktijk leert dat dit aan openbare universiteiten in afnemende mate het geval is.

De theologie aan de openbare universiteiten in Nederland incasseert forse klappen; hierdoor

1 Dit is de tekst van het openingscollege dat ik in verkorte vorm heb uitgesproken bij de opening van het academisch jaar aan de Theologische Universiteit Kampen uitgaande van de Gereformeerde Kerken (Vrijgemaakt). 
kan gemakkelijk de indruk ontstaan, dat theologie als zodanig een aflopende zaak is. Naar aanleiding van deze rede stelde een journaliste me de vraag: Zal het over 25 jaar nog mogelijk zijn om theologie in Nederland te studeren? Mijn antwoord is: ja. Neem de Theologische Universiteit Kampen als voorbeeld: hier is het studentenaantal de afgelopen jaren relatief stabiel. lets soortgelijks geldt voor een aantal andere confessionele instellingen. Dat deze instellingen bovendien groot belang aan theologie hechten, hoeft geen betoog. Het voortbestaan van de theologie aan deze instellingen is daarom vooralsnog gewaarborgd. Sterker nog, het relatief belang van theologie aan deze instellingen groeit. Waar de Theologische Universiteit Kampen in het verleden een relatief kleine opleiding was, die wegviel tegen opleidingen met vele tientallen studenten per jaar, bent $U$ nu getalsmatig in theologisch Nederland een factor om rekening mee te houden. Uw marktaandeel is gegroeid. En dat geldt niet alleen voor $\mathrm{U}$, maar bijvoorbeeld ook voor de Theologische Universiteit Apeldoorn en meer in het algemeen voor de protestantse theologische opleidingen: die houden stand waar openbare opleidingen teloorgaan.

Als kerkelijke of confessionele theologie relatief in opkomst is, dan is het tijd voor een nieuw zelfbewustzijn en een nieuw elan. Dat nieuw elan is niet alleen voor de universiteiten van belang, maar ook voor de maatschappij. Theologie heeft immers niet alleen een kerkelijke maar ook een publieke functie. Wij kunnen de theologie niet straffeloos afschaffen, niet alleen omdat de kerk dan geen goed opgeleide predikanten meer zou hebben, maar ook omdat de maatschappij erdoor zou verarmen. Zo is door het werk van prof. Hooykaas en vele anderen ${ }^{2}$ duidelijk geworden dat het niet toevallig is dat de moderne natuurwetenschap in het christelijk Westen ontstond. Het christendom - en volgens de agnost Floris Cohen zelfs meer in het bijzonder het protestantisme (Cohen - vormde de levensbeschouwelijke achtergrond waartegen de moderne wetenschap tot bloei kon komen. Het christendom

1. ziet de werkelijkheid zelf niet als goddelijk maar als schepping van God: je mag de werkelijkheid dus onderzoeken;

2. ziet de werkelijkheid als schepping van een intelligentie die ons te boven gaat: je kunt de werkelijkheid dus zinvol onderzoeken;

3. ziet de werkelijkheid als bron van kennis over God: het is dus goed, de werkelijkheid te onderzoeken.

Het verbaast daarom niet dat de eerste moderne natuurwetenschappers veelal christenen en vaak ook theologen waren; juist hun opvattingen maakten die natuurwetenschap mogelijk (Sarot, 2006:118-119). Juist daarom is het zo ironisch dat atheïsten als Herman Philipse zich nu op grond van de wetenschap tegen het christendom keren. James McAllister, een atheïstisch wetenschapsfilosoof, heeft Philipse onlangs gekapitteld over diens opvatting dat religie niets verklaart dat de wetenschap niet beter verklaart. Volgens McAllister verklaart religie tenminste vier fundamentele aspecten van onze werkelijkheid die de wetenschap niet verklaart, en tenminste voorlopig ook niet zal verklaren:

1. Het ontstaan van het universum;

2. Het ontstaan van leven;

3. Het ontstaan van bewustzijn;

4. Het ontstaan van moraal (McAllister 2012).

McAllister heeft wel vragen bij de verklaringen die religies van deze zaken geven, maar hij

2 Hooykaas 1972; voor meer literatuur, zie Sarot 2006: 118-119.

Theologie: een dwaze wetenschap? $\mathbf{2 8 5}$ 
waardeert desalniettemin dat ze een verklaring geven. Ik onderschrijf dat hier graag, en voeg er aan toe dat een samenleving die geen antwoord meer heeft op een vraag als die waar onze moraal vandaan komt, in feite beginselloos is. Let wel: ik claim niet dat iedereen in een samenleving het eens moet zijn over vragen als: waar komt onze moraal vandaan? Het kan geen kwaad dat mensen erover van mening verschillen en over dat verschil in gesprek gaan. Het kan ook geen kwaad als de discussies hoog oplopen. Maar wanneer het dominante sentiment in een samenleving wordt "het leven is zomaar ontstaan", "de moraal is zomaar ontstaan", enzövoort, dan ontstaat er een moreel vacuüm waarin niets meer waard is dan iets anders en waarin de grootste schreeuwers altijd gelijk krijgen. Er ontstaat dan een samenleving die zelf zo weinig normatief kapitaal ${ }^{3}$ heeft dat wanneer mensen van buiten komen die wel heldere opvattingen, waarden en idealen hebben, deze mensen al heel snel als bedreigend worden ervaren. Op dit moment zie je dat in de Nederlandse samenleving gebeuren met moslims uit niet-Westerse culturen. Als onze samenleving sterke eigen idealen had, zou het debat met "vreemde" idealen interessant zijn; maar waar die idealen goeddeels ontbreken, is er slechts een leegte. En leegtes hebben nu eenmaal de neiging om vol te lopen. Daarom voelen velen zich bedreigd door de islam en volgt een xenofobe reactie - een reactie die veel sterker is dan je zou mogen verwachten op grond van de zes procent moslims in Nederland, moslims die zich in een zwakke sociaal-economische positie bevinden en die een geloof belijden dat voor het grootste deel van de Nederlanders geen enkele aantrekkingskracht heeft (Van Rossum 2010:6).

Het is één van de taken van de theologie, bij te dragen aan het normatief kapitaal van een samenleving. En waar de openbare theologie dit laat liggen, wordt het een taak van de confessionele of kerkelijke theologie. De vraag is echter: is confessionele of kerkelijke theologie wel tegen deze taak opgewassen? Is confessionele theologie niet uit haar aard gericht op een doelgroep, en is zij daarom ook niet uitsluitend voor die doelgroep interessant?

\section{IS CONFESSIONELE THEOLOGIE EEN HETERONOME WETENSCHAP?}

Als wij de vraag aan de orde stellen, in hoeverre de confessionele of kerkelijke theologie een zinvolle bijdrage kan leveren aan de publieke taak die ik zojuist aan de theologie heb toegeschreven, dan kunnen wij niet heen om het feit dat theologie het moeilijk heeft in de wetenschappelijke wereld. In een moment van zelfspot grapte Paul van Geest ooit dat de theologie de enige wetenschap is die een object bestudeert waarvan het niet zeker is of het bestaat. ${ }^{4}$ Herman Philipse betoogde dat alles er op wijst dat theologie geen wetenschap kan zijn. Hij trekt daar de conclusie uit dat de Nederlandse staat op moet houden de theologie als wetenschap te financieren (Philipse 1996). Philipse heeft zijn zin niet gekregen, maar de figuur van de kerkelijk hoogleraar, waartegen hij in hetzelfde artikel fulmineerde, is inmiddels uit de wet verdwenen. En de Nederlandse Organisatie voor Wetenschappelijk Onderzoek financiert steeds minder theologisch onderzoek. Onderzoek in de dogmatiek en ander onderzoek dat heel duidelijk voortkomt uit een bepaalde kerkelijke traditie, hoe goed ook, lijkt bij NWO nagenoeg kansloos. Beoordelingscommissies - die bijna altijd in meerderheid uit niettheologen bestaan - oordelen negatiever over het belang en de wetenschappelijke kwaliteit van een onderzoeksvoorstel naarmate het duidelijker religieus gemotiveerd is. Als wij dit zien in samenhang met de ontwikkelingen aan de openbare universiteiten, dan kunnen wij niet anders dan concluderen dat de door Philipse voorgestane verbanning van de theologie van de academie weliswaar nog niet voltooid is, maar dat er wel degelijk een begin mee is gemaakt.

\footnotetext{
3 Onder het "normatief kapitaal van een samenleving" versta ik het geheel van zingevende en normatieve opvattingen dat het publieke discours van een samenleving bepaalt.

4 In zijn inaugurele rede aan de Vrije Universiteit Amsterdam, 2006.
} 
Het voornaamste bezwaar tegen de theologie is niet dat haar object irrelevant is; iedereen is het er over eens dat religie een belangrijke factor in de samenleving is, en daarom ook een belangrijk object van studie is. Het voornaamste bezwaar is evenmin dat de theoloog een gelovig perspectief inneemt. Ongelovigen zullen vaak moeite hebben met een gelovig perspectief, maar tegelijk zullen zij toegeven dat alle geesteswetenschap, in de woorden van H.W. von der Dunk (1994:56), "gebonden aan standplaats, tijd en wereldbeeld" van de wetenschapper is. ${ }^{5}$

$\mathrm{Nee}$, het grote probleem van confessionele theologie is voor de seculiere wetenschapper dat confessionele theologie onvrij zou zijn. Tegen de achtergrond van de idealen van de verlichting is niet moeilijk in te zien, wat het probleem is. Een van de belangrijkste van die idealen is dat de mens vrij moet zijn in het gebruik van zijn rede. Immanuel Kant zegt het in zijn klassieke artikel "Wat is Verlichting?" als volgt: "Verlichting is het uittreden van de mens uit de onmondigheid die hij aan zichzelf te wijten heeft. Onmondigheid is het onvermogen om zich zonder leiding van een ander van zijn verstand te bedienen" (Kant 1988:59). Enkele bladzijden verderop in hetzelfde opstel legt Kant verder uit:

Voor deze verlichting wordt niets anders gevraagd dan vrijheid, en wel de onschadelijkste vrijheid onder alles wat maar vrijheid mag heten, namelijk de vrijheid om van zijn rede in alle opzichten een openlijk gebruik te maken. Nu hoor ik echter van alle kanten zeggen: redeneer niet! De officier zegt: Redeneert niet, maar exerceer! De belastinginspecteur: redeneer niet, maar betaal! De geestelijke: redeneer niet, maar geloof! ... Hier is overal beperking van de vrijheid. Welke inperking echter is hinderlijk voor de verlichting? Welke niet ...? Ik antwoord: het openlijke gebruik van zijn rede moet te allen tijde vrij zijn, en dat alleen kan verlichting onder mensen tot stand brengen; het privé gebruik van de rede mag echter meer dan eens zeer nauw beperkt zijn, zonder toch daardoor de vooruitgang van de verlichting bijzonder te hinderen (62-63)

Dit roept de vraag op, wat Kant precies verstaat onder publiek gebruik en privé gebruik. Deze vraag beantwoordt hij als volgt:

Ik versta onder het openlijke gebruik van zijn rede het gebruik, dat iemand als geleerde van haar maakt ten overstaan van de lezende wereld. Het privé-gebruik noem ik het gebruik, dat hij op een bepaalde hem toevertrouwde burgerlijke post of in een ambt van zijn rede mag maken (62-63).

Even verderop past Kant dit toe op de geestelijke: in zijn verkondiging dient hij zich te houden aan de leer van de kerk die hij dient, terwijl hij in zijn wetenschappelijk bezig zijn daarvan volstrekt en onbeperkt vrij moet zijn. Als geestelijke maakt hij dus privé gebruik van zijn verstand, als geleerde openlijk (64-65). Ook al zouden wij juist geneigd zijn om het gebruik dat de geestelijke als geestelijke van zijn verstand maakt, publiek te noemen, ${ }^{6}$ de inhoud van de onderscheiding is duidelijk. Kant heeft er alle begrip voor dat een predikant binnen de grenzen van het kerkelijk dogma moet blijven, maar een wetenschapper moet vrij van elke bevoogding kunnen denken.

De invloed van deze denkwijze van Kant kan nauwelijks overschat worden. Tot op de dag van vandaag hebben veel mensen er wel begrip voor dat een geestelijke als geestelijke niet zomaar alles kan zeggen, zoals een militair als militair niet alles kan zeggen. It goes with the job, denken ze dan. Maar een wetenschapper moet altijd in alle vrijheid onderzoek kunnen doen

5 Von der Dunk zegt dit van de geschiedwetenschap. Zie over perspectiviteit ook Sarot 2006, 148-151. 6 Zie Delfgaauw in zijn inleiding op Kant 1988, 27. 
en kunnen spreken en publiceren. Daarmee wordt confessionele theologie een contradictio in terminis, tenminste, als wij "theologie" opvatten als een wetenschappelijke discipline. Immers, confessionele theologie is gebonden aan een confessie - en staat in dat opzicht gelijk aan de preek van een predikant - terwijl theologie als wetenschap vrij zou moeten zijn. Als theologie een heteronome wetenschap is, is het geen wetenschap.

Als er één frase is die zowel karakteristiek is voor de confessionele theologie als suggereert dat theologie een heteronome wetenschap is, is het wel het Latijnse adagium: Lex orandi, lex credendi. De wet van het gebed is de wet van het geloof, zo zou je kunnen vertalen. Onder dit adagium wordt meestal verstaan dat de christelijke gebedspraktijk en de christelijke liturgie mede bepalen wat wij moeten geloven. ${ }^{7}$ Gebed en liturgie zijn dan dus een gezaghebbende bron van theologie. Dat betekent ook dat de christelijke liturgie een argument, ja zelfs een doorslaggevend argument in het theologisch debat kan zijn. De gezaghebbende theoloog Alister McGrath geeft hiervan de volgende twee voorbeelden. In de vroege kerk beargumenteerden de gnostici, op basis van het door hen scherp aangezette onderscheid tussen het materiële en het spirituele, dat materie inherent kwaad was. Ireneus gebruikte in zijn weerlegging van de gnostici als argument dat water, brood en wijn worden gebruikt in de christelijke sacramenten. Als dergelijke materiële zaken een belangrijke plaats innemen in de christelijke liturgie, dan kunnen zij toch niet inherent kwaad zijn? ${ }^{8}$ McGrath's tweede voorbeeld heeft betrekking op de discussie met Arius (ca. 250-336), die betoogde dat Jezus het hoogste van Gods schepselen was. Athanasius (296-373) bracht hier tegenin dat de christelijke liturgische praktijk, waarin christenen tot Jezus bidden en Hem aanbidden, onverenigbaar is met de opvatting dat Jezus een schepsel is. Als Arius gelijk heeft, is de aanbidding van Jezus een vorm van afgoderij. ${ }^{9}$

De discussie van Arius en Athanasius is een prachtige illustratie van het onbehagen van hedendaagse seculiere wetenschappers hebben bij confessionele theologie. Athanasius is de confessionele theoloog die op basis van de gebedspraktijk en de liturgie van de kerk het denken van Arius kritiseert en met zijn kritiek de kerk achter zich krijgt. Arius neemt in dit debat de positie van de rationalist in die betoogt dat als Jezus God was, christenen een veelgodendom accepteerden. Als de liturgie dat suggereert, behoeft de liturgie correctie op grond van het redelijk denken (McGrath 1994:191). De hedendaagse verdediger van de vrijheid van de wetenschap zal zich in dit debat derhalve positie kiezen voor Arius. Kortom, met de spreuk lex orandi, lex credendi zitten wij midden in de problematiek van de academische geloofwaardigheid van confessiegebonden theologie.

Voor ik daar meer over zeg wil ik nog iets zeggen over de verhouding van de protestantse theologie tot dit adagium. Die is enigszins dubbelzinnig (vgl. Wainwright 1980:218-219). Enerzijds is er waardering voor dit adagium en zijn er theologen die erbij aansluiten. Zo is de genoemde Alister McGrath per saldo positief, hoewel hij wel opmerkt dat niet alleen de liturgie als norm voor de theologie kan gelden, maar ook - omgekeerd - de theologie ontsporingen in de liturgie moet kunnen kritiseren.10 De Lutheraanse theoloog Gerhard Ebeling gaat een stap verder, en geeft in feite een hedendaagse herformulering van het adagium wanneer hij zegt dat

\footnotetext{
7 Waddell 2009s noemt twee alternatieve interpretaties van het adagium. Volgens de eerste betekent het dat ons ons gebed en onze liturgie de inhoud van ons geloof weerspiegelen, en volgens de tweede dat geloofsinhoud en liturgie identiek zijn. Vgl. ook Wainwright 1980:218.

8 Ireneus, Adversus Haereses IV 18,4-5.

9 Athanasius, Epistula ad Adelphium episcopum et confessorem, 3-4. Cf. McGrath 1994:191.

10 McGrath 1994:191-2. Dat McGrath positief is, is niet zo verbazingwekkend, want volgens het Anglicaanse kerkrecht is de leer van de Anglicaanse kerk te vinden in de Thirty-Nine Article of Religion, The Book of Common Prayer, en the Ordinal. Zie het bekroonde essay van Natacha-Ingrid Tinteroff (2012). Pius XII (1947), legt het primaat bij de relatie lex orandi - lex credendi heel duidelijk bij de lex credendi zoals gearticuleerd door het leergezag. Vgl. Wainwright 1980: 222-224.
} 
het gebed een hermeneutische sleutel tot de Godsleer is:

Das Phänomen des Gebetes wird somit zum hermeneutischen Schlüssel der Gotteslehre. Von da aus öffnet sich das Verständnis für das Gott zugesprochene Sein und für die Gott zugesprochene Attribute. Die Lehre von Gott ist deshalb in Korrelation zur Lehre vom Gebet zu entwerfen (Ebeling 1979:193).

De Zuid-Afrikaans/Nederlandse calvinistische theoloog Vincent Brümmer zet zijn grote project over de Godsleer dat zou resulteren in boeken als Over een persoonlijke God gesproken (Brümmer 1988) en Liefde van God en mens (Brümmer 1993) dan ook in met een boek over het gebed, waarin hij de opvatting van Ebeling citeert en waarin hij daadwerkelijk uitgaat van een analyse van de gebedsrelatie met God om op basis daarvan te komen tot een analyse van de eigenschappen van God (Brümmer 1985). ${ }^{11}$ Brümmers opvattingen heb ben vervolgens veel invloed gehad in protestants Nederland. Men ziet dit bijvoorbeeld ook terug in de dissertatie van Dolf te Velde: Paths beyond Tracing out (Te Velde 2010), waarin Brümmer en zijn leerlingen met veel waardering worden beschreven. Men kan dus zeker niet zeggen dat dit principe dat zo nauw verbonden is met confessionele theologie, Lex orandi, lex credendi, vreemd is aan de protestantse theologie. Maar tegelijkertijd zal duidelijk zijn dat de Reformatie niet het hoogste gezag toekent aan de lex orandi: het is niet sola liturgia of sola oratione maar sola scriptura. Waar de Schrift het hoogste gezag heeft, komt de wet van het gebed - en zeker die van de liturgie - op een tweede plaats. De achterdocht van de Reformatie tegenover het principe dat de gebedspraktijk de geloofsleer bepaalt is ook te begrijpen vanuit concrete toepassingen. Waar het principe wordt gebruikt om Gnostici of Arianen te weerleggen, hebben protestantse theologen geen probleem. Maar het is bijvoorbeeld ook gebruikt om de leer van het vagevuur te verdedigen: als wij voor overledenen mogen bidden, moet hun toestand in het hiernamaals ook kunnen verbeteren (Wainwright 1980:450-451). Hier heeft de protestantse theologie, op basis van het gezag van de Schrift, duidelijk een andere visie. ${ }^{12}$

Laten wij dan nu eens nader bezien waar het lex orandi, lex credendi vandaan komt en wat er precies mee is bedoeld. In tegenstelling tot wat vaak wordt gedacht, is dit adagium niet letterlijk terug te vinden bij de kerkvaders. Het is ontleend aan een werk dat lang aan Paus Celestinus I (†432) werd toegeschreven omdat het in het manuscript waarin het werd overgeleverd volgde op een brief van Celestinus. Tegenwoordig denkt men dat het werd geschreven door de monnik Prosper van Aquitanië, secretaris van Paus Leo de Grote (400-461) (De Clerck 1994:180). Letterlijk zegt hij ut legem credendi lex statuat supplicandi (Hvang 2009:224): zodat de lex supplicandi de wet van het geloof bepaalt. Eén dubbelzinnigheid die de formulering lex orandi, lex credendi aankleeft, is hiermee in ieder geval verdwenen. Aangezien in het Latijn de woordvolgorde niet de betekenis bepaalt, is niet duidelijk wat in de bekende formulering nu het onderwerp is en wat het naamwoordelijk deel van het gezegde. Je kunt het adagium ook lezen zoals Pius XII

11 Het citaat van Ebeling bevindt zich op blz. 167, waar Brümmer ook nog als opvatting van Gerhard Sauter citeert dat "unser reden von Gott nur möglich ist auf Grund des Redens zu Gott". Sauter argumenteert: "Die Theologie sehe ich deshalb auf das Gebet angewiesen und in sie verankert, weil im Beten die Grundunterscheidungen ausgesprochen werden, die die Wirklichkeitserfahrung des Glaubens konstituieren; Sache der Theologie ist es, die durch diese Unterscheidungen gewonnenen Erkenntnisse in ihrem Zusammenhang und in ihrer Zuordnung aszusagen" (Sauter 1981:219, 227).

12 Andere typisch rooms-katholieke, door protestanten afgewezen, theologische opvattingen die wel met een beroep op de lex orandi zijn verdedigd vanuit liturgische teksten zijn de onbevlekte ontvangenis van Maria tenhemelopneming van Maria met lichaam en ziel (Wainwright 2003:88-89). 
het wilde lezen: de lex credendi bepaalt de lex orandi. Bij Prosper kan dat niet: de lex supplicandi is het onderwerp, de lex credendi het lijdend voorwerp. Maar dat betekent nog niet dat precies duidelijk is wat Prosper bedoelt. Prosper ondersteunt in het geschrift waaruit het adagium afkomstig is met een reeks citaten van Paus Innocentius I (401-417), Paus Zosimus (417-418) en het Concilie van Carthago (418) de Augustiniaanse, antiPelagiaanse positie. Uit de citaten volgt, zo zegt hij, dat "het begin van een goede wil, de groei van onze prijzenswaardige inspanningen en de volharding tot het einde aan de genade van Christus moeten worden toegeschreven. " Hier zegt Prosper dus dat de kerk steeds heeft geleerd dat alle stadia van geloof - begin, groei en volharding tot het einde - aan de genade van Christus moeten worden toegeschreven. Daarmee richt hij zich tegen Pelagius en de Semipelagianen die het belang van de menselijke factor sterker beklemtoonLaten wij in dit verband ook kijken naar de voorbeden die onze priesters, op gezag van de apostelen, overal in de wereld en in de hele katholieke kerk op dezelfde wijze bidden. Laat deze gebedsopdracht (de lex supplicandi) de inhoud van het geloof (de lex credendi) bepalen. Wanneer immers onze voorgangers naar hun opdracht bidden, bevelen zij de hele mensheid bij de Goddelijke barmhartigheid aan en bidden en smeken:

dat geloof mag worden gegeven aan de ongelovigen dat afgodendienaars mogen worden bevrijd van hun dwaling [...] dat ketters bekeerd mogen worden en het katholiek geloof mogen aanvaarden. ${ }^{13}$

En zo gaat Prosper nog even door met een reeks van voorbeden gericht op joden, zondaars en doopleerlingen, waarin steeds opnieuw aan God wordt gevraagd hen te bekeren. In de zojuist geciteerde passage zet Prosper zijn aanval op het Pelagiaans gedachtegoed voort met een beroep op de Bijbel. Hij doet dat op een heel slimme manier, door zich te beroepen op een van hun bewijsplaatsen: het begin van 1 Timoteüs 2 .

13 Prosper van Aquitanië, Liber praeteritorum sedis apostolicae episcoporum auctoritates de gratia dei et libero voluntatis 8 Migne PL 51:209-210. Engelse vertaling in: De Letter 1963: 183-184 en in De Clerck 1994:181. In de Nederlandse vertaling die ik in de hoofdtekst geef probeer ik de betekenis goed weer te geven maar maak ik de tekst iets minder barok. De Latijnse tekst luidt:

Praeter beatissimae et apostolicae sedis inviolabiles sanctiones, quibus nos piissimi patres, pestiferae novitatis elatione dejecta, et bonae voluntatis exordia, et incrementa probabilium studiorum, et in eis usque in finem perseverantiam ad Christi gratiam referre docuerunt, obsecrationum quoque sacerdotalium sacramenta respiciamus, quae ab apostolis tradita, in toto mundo atque in omni catholica Ecclesia uniformiter celebrantur, ut legem credendi lex statuat supplicandi.

Cum enim sanctarum plebium praesules mandata sibimet legatione fungantur, apud divinam clementiam humani generis agunt causam, et tota secum Ecclesia congemiscente, postulant et precantur ut infidelibus donetur fides,

ut idololatrae ab impietatis suae liberentur erroribus, ut Judaeis, ablato cordis velamine, lux veritatis appareat, ut haeretici catholicae fidei perceptione resipiscant, ut schismatici spiritum redivivae charitatis accipiant, ut lapsis poenitentiae remedia conferantur, ut denique, catechumenis ad regenerationis sacramenta perductis, coelestis misericordiae aula reseretur. Haec autem non perfunctorie neque inaniter a Domino peti, rerum ipsarum monstrat effectus: quandoquidem ex omni errorum genere plurimos Deus dignatur attrahere, quos erutos de potestate tenebrarum transferat in regnum Filii charitatis suae (Coloss. I, 13), et ex vasis irae faciat vasa misericordiae (Rom. IX, 22). Quod adeo totum divini operis esse sentitur, ut haec efficienti Deo gratiarum semper actio, laudisque confessio, pro illuminatione talium vel correctione referantur. 
1 Allereerst vraag ik dat er voor alle mensen gebeden wordt, dat er smeekbeden, voorbeden en dankgebeden voor hen worden uitgesproken. 2 Bid voor alle koningen en gezagsdragers, opdat we rustig en ongestoord kunnen leven, in alle vroomheid en waardigheid. 3 Dat is goed en welgevallig in de ogen van God, onze redder, 4 die wil dat alle mensen worden gered en de waarheid leren kennen. 5 Want er is maar één God, en maar één bemiddelaar tussen God en mensen, de mens Christus Jezus, 6 die zichzelf gegeven heeft als losgeld voor allen, als het getuigenis voor de vastgestelde tijd. (NBV)

In vers 4 staat dat God wil dat alle mensen worden gered. Aangezien in de praktijk niet alle mensen worden gered, moet dat wel betekenen - zo redeneerden de Pelagianen - dat er in de praktijk voor de redding van een mens meer nodig dan Gods wil alleen: de wilsact van die mens. ${ }^{14}$ In De vocatione omnium gentium I 12-15 besprak Prosper deze tekst al eerder maar trekt hij heel andere conclusies dan de Pelagianen. Uit de oproep voor alle mensen te bidden, trekt Prosper de conclusie dat onze redding uiteindelijk geheel van God afhankelijk is. Dat uiteindelijk niet alle mensen gered worden is een mysterie, zoals er aangaande God wel meer zijn, maar doet niets af aan het feit dat onze redding geheel en alleen van God afhankelijk is.

In onze tekst komt Prosper terug op 1 Timoteüs 2: 1-6. De lex supplicandi waarover hij spreekt is de opdracht om te bidden voor alle mensen; het is die universele gebedsopdracht die de inhoud van ons geloof moet bepalen. Prosper doelt met lex supplicandi derhalve niet in algemene zin op de inhoud van onze gebeden en liturgie, maar specifiek op de universele gebedsopdracht van Paulus in 1 Timoteüs $2 .{ }^{15}$ En met de lex credendi doelt hij niet op geloofsinhouden in het algemeen, maar op het specifieke punt dat voor hem met de gebedsopdracht verbonden is: alle mensen zijn in hun belangrijkste keus, die voor of tegen God, uiteindelijk van God zelf afhankelijk. Dat blijkt zowel uit de universele gebedsopdracht als uit de wijze waarop de kerk die invult, want de voorbeelden van voorbeden die Prosper geeft zijn uiteindelijk allemaal voorbeden om bekering. Als wij bidden om bekering, zo lijkt Prosper te willen zeggen, veronderstellen wij dat die bekering van God komt.

Zowel de Semipelagianen als Prosper gaat het om vers 4, waarin staat dat God wil dat alle mensen tot geloof komen. Prosper legt dit vers uit vanuit zijn directe context: vers 1 over het bidden voor alle mensen, en vers 6 over de ene Middelaar, Jezus Christus. Zijn uitleg is dat omdat God wil dat alle mensen worden gered (vs. 4), wij God om die redding moeten vragen (vs 1), want er is maar één weg: Jezus Christus (vs. 6). De Pelagiaanse exegese die is gebaseerd op het contrast tussen God universele heilswil (vs. 4) en het ervaringsfeit dat niet alle mensen worden gered, kan Prosper negeren omdat het feit dat niet alle mensen gered worden niet in de directe omgeving van vers 4 wordt genoemd.

Vervolgens gaat Prosper nog even door en laat hij zien dat zijn uitleg van 1 Timoteüs 2 overeenstemt met enkele andere teksten uit het Nieuwe Testament:

Dat deze smeekbeden niet zomaar, alleen voor de vorm, tot God worden gericht, blijkt wel uit hun effect. Steeds weer onttrekt God talloze mensen aan hun dwalingen en redt ze uit de macht van de duisternis om ze over te brengen naar het rijk van zijn geliefde Zoon (Col. 1:13), en van objecten van toorn maakt hij objecten van barmhartigheid (Rom. 9:22-23).

14 Augustinus, Contra Iulianum IV 8.42; vgl. Hwang, Intrepid Lover, 75. Zie ook Prosper van Aquitanië, De vocatione omnium gentium I 12-15.

15 In De vocatione omnium gentium gebruikt hij voor dezelfde gebedsopdracht de uitdrukkingen doctrinae apostolicae regula en lex supplicationis. Zie Van Slyke 2004:130-151; vgl. Wainwright 2003:88; Waddell 2009b. 
En de kerk is er zozeer van overtuigd dat dit uitsluitend aan Gods handelen te danken is dat zij God zonder ophouden dankt en prijst dat Hij deze mensen verlicht en weer op de goede weg zet.

Zo zet Prosper met nog eens twee verwijzingen naar brieven van Paulus en een nieuw beroep op de gebedspraktijk van de kerk de puntjes op de i en besluit waar hij begon: anders dan de Semipelagianen denken is de bekering van mensen uitsluitend en alleen te danken aan God.

Laten wij nu in twee stappen de oogst van het voorgaande binnenhalen en de vraag aan de orde stellen in hoeverre hiermee de bezwaren van protestantse theologen respectievelijk seculiere wetenschappers tegen het adagium Lex orandi, lex credendi zijn ondervangen. Eerst het voorbehoud van de protestantse theologie. Dit kwam hierop neer, dat dit adagium een aan de Schrift vreemde norm oplegt aan de theologie. Waar het Prosper van Aquitanië betreft, komt dit bezwaar te vervallen nu blijkt dat de lex supplicandi waarover hij het heeft gezien moet worden in aanvulling op de kerkelijke belijdenis en het Bijbels getuigenis, en dat deze 'wet' bovendien in de eerste plaats betrekking heeft op de Bijbelse opdracht om voor de redding van alle mensen te bidden uit 1 Timoteüs 2 . Waar dit adagium uit zijn context wordt gehaald en in algemene zin gaat voorschrijven dat de inhoud van gebed en liturgie ${ }^{16}$ de inhoud van het geloof bepaalt, krijgt het een andere betekenis dan in het werk van Prosper. Dat is in principe nog geen reden om deze interpretatie af te wijzen. De protestantse theoloog zal hier terughoudend zijn in zijn oordeel: enerzijds is de Schrift de hoogste norm, anderzijds zal de beproefde liturgie van de kerk in veel gevallen Schriftgetrouw zijn, en is het daarom wel degelijk een aanwijzing van belang wanneer de liturgie van de kerk Jezus aanbidt als God (dit tegen de Arianen), water, brood en wijn gebruikt in de sacramenten (dit tegen de gnostici), en bidt en dankt om de bekering van joden, heidenen, afvalligen of zondaars (tegen de Semipelagianen). De lex orandi kan daarom ook binnen de protestantse theologie zoals bij Prosper een legitieme bouwsteen zijn in een cumulatieve argumentatie voor een bepaalde positie, een argumentatie waarin de Schrift uiteindelijk het doorslaggevende gewicht in de schaal legt. ${ }^{17}$

Laten wij vervolgens kijken wat dit betekent voor de seculier-wetenschappelijke kritiek op dit adagium, namelijk dat het theologie tot een heteronome wetenschap zou maken. Ook dit kan men nu niet langer handhaven. Met betrekking tot Prosper niet, omdat gebed en liturgie bij hem niet het gezag van een wet hebben. En ook niet met betrekking tot die theologen die het lex orandi, lex credendi breder willen toepassen, want ook voor hen heeft het niet de kracht van een dogma in de trant van liturgia locuta, causa finita.

In dit verband wil ik wijzen op een dubbelzinnigheid in het begrippenpaar heteronomie / autonomie. Autonomie betekent letterlijk 'jezelf tot wet zijn.' Dan gaat het om morele autonomie. In die zin hebben christenen moeite met autonomie: wij erkennen een macht boven ons. Maar bij Kant kwamen wij een andere zin tegen: zonder leiding van een ander je verstand gebruiken. Sapere aude! Durf je van je eigen verstand te bedienen! Je zou kunnen zeggen: dit is intellectuele

16 Dat Prosper ook uit liturgische rituelen dogmatische conclusies trekt, blijkt uit hfdst. 9 van de Auctoritates, waar hij zich tegen de Semipelagianen beroept op de exorcismen die voorafgaan aan de eigenlijke doop. Van Slyke 2004 gaat dan ook te ver wanneer hij stelt dat "any temptation to equate Prosper's 'lex supplicandi' with 'liturgy' ought to be resisted".

17 Ook naar Rooms-Katholieke opvatting zal men van de lex orandi geen knock down argument maken en zal deze hooguit een plaats hebben binnen een bredere argumentatie. Verschil is wel, dat de Schrift in dit geval weliswaar zeer belangrijk is, maar niet doorslaggevend. Uiteindelijk is het magisterium doorslaggevend. Zie Pius XII 1947:47. 
autonomie. Daar heeft een christen geen moeite mee, en zeker een christenwetenschapper niet. Ook wanneer de christenwetenschapper vóór hij aan de slag gaat, God om diens leiding vraagt, ontslaat dat de wetenschapper niet om zélf te denken. God en mens zijn geen concurrenten: Gods leiding concurreert niet met ons denken. Dit geldt in alle wetenschap, ook in de theologie, ook daar waar de theoloog zich onder het gezag van de Schrift stelt. Dat God Zijn wil heeft geopenbaard, betekent niet dat de mens niet meer zelf hoeft te denken als hij wil weten wat die wil dan precies inhoudt.

Daar kan zelfs wetenschappelijk denken voor nodig zijn. Wij zien dat in Prospers uitleg van 1 Timoteüs 2, wij zien dat bijvoorbeeld ook in de vraag wat de Bijbel te zeggen heeft over de vrouw in het ambt (Klinker-de Klerck 2011). Het antwoord op een dergelijke vraag is geen invuloefening waarbij als je op de goede plaatsen de goede dingen invult, er vanzelf de juiste uitkomsten uit komen rollen. Nee, het gaat hier om een hermeneutisch proces waarin verschillende Bijbelteksten, en ook verschillende genres Bijbelteksten, met elkaar in verband moeten worden gebracht en waarin de vraag aan de orde moet komen: als wij de cultuur waarin deze teksten werden geschreven verdisconteren, wat moeten wij dan als Gods boodschap in deze teksten zien? Dat dit een denkproces is en geen invuloefening, blijkt ook wel uit het feit dat verschillende kerken op dit punt - zoals op andere punten - tot verschillende conclusies komen.

Mijn conclusie is derhalve, dat christelijke theologie die het adagium lex orandi, lex credendi serieus neemt, in tegenstelling tot wat veelal wordt gedacht kan voldoen aan dat hedendaagse ideaal van wetenschap dat stelt dat de wetenschapper in alle vrijheid gebruik moet kunnen maken van het eigen verstand. Christelijke theologie wordt niet gediskwalificeerd door haar methode.

\section{THEOLOGIE EN RELEVANTIE: HET VOORBEELD VAN ERASMUS}

De vraag is niet alleen: hoe kan confessionele theologie wetenschappelijk geloofwaardig zijn? Nee, de vraag luidt ook: hoe kan confessionele theologie een bijdrage leveren aan het publieke domein, aan het intellectuele debat in onze samenleving? Er zijn ook in onze tijd steeds weer boeken die in het publieke intellectuele debat een zodanige rol spelen, dat zij als het ware de rol krijgen van een gedeeld referentiekader, zoals bijvoorbeeld Charles Taylor, Sources of the Self (Cambridge, MA, 1989), Francis Fukuyama, The End of History and the Last Man (NY: Free Press, 1992), Samuel Huntington, The Clash of Civilizations and the Remaking of World Order (NY: Simo \& Schuster, 1996). In Nederland kun je recent bijvoorbeeld denken aan Dick Swaab, Wij zijn ons brein (Amsterdam: Contact, 2010). Christelijke boeken bereiken meestal niet een dergelijke status; het laatste boek dat dat wel deed was, denk ik, Harry Kuitert, Het algemeen betwijfeld christelijk geloof (Baarn: Ten Have, 1992), en dat boek was vooral kritisch over geloof. Toen ik jong was, hadden boeken van Schillebeeckx en Berkhof die status: op de meest onverwachte plaatsen herkende je de opvallende rug van Berkhofs Christelijk Geloof, en een beetje intellectueel had ook wel een boek van Schillebeeckx in de kast. Kan gelovige, opbouwende theologie nog altijd een dergelijke rol vervullen, of ligt die tijd definitief achter ons?

Hier wil ik daar iets over zeggen aan de hand van een klassieke Nederlandse theoloog die verschillende van dergelijke boeken heeft geschreven, waarvan er één de eeuwen heeft doorstaan en nog altijd door protestant, katholiek en humanist gelezen en gewaardeerd wordt: Erasmus van Rotterdam. Mijn keuze voor Erasmus is mede ingegeven door het feit dat Erasmus in onze tijd op de eerste plaats wordt gezien als geleerde en humanist en hij als het ware een merknaam geworden is van zodanige kwaliteit, dat ook een alom gerespecteerde seculiere universiteit zich niet schaamt, zijn naam te voeren. Je kunt je moeilijk voorstellen dat de Rotterdamse Universiteit zichzelf de Johannes Calvijn Universiteit Rotterdam zou noemen, 
of de Thomas van Aquino Universiteit Rotterdam; Thomas en Calvijn worden weliswaar als grote geleerden erkend, maar worden toch teveel gezien als behorend bij één specifieke kerk. Voor Erasmus ligt dat kennelijk anders. Een tweede reden om me te concentreren op Erasmus, is dat hij een vaktheoloog was die grote invloed had op de publieke opinie van zijn tijd. Een derde reden is, dat Erasmus een Rooms-Katholieke theoloog uit de tijd van de Reformatie is die, hoewel hij Rooms-Katholiek is gebleven, toch grote invloed op de Reformatie heeft uitgeoefend, zowel op Luther (Augustijn 1962; Huizinga 1936) als op Calvijn (Wendel 1950 :12-20), Tyndale (DeCoursey 1966) en anderen.

Erasmus schreef tenminste drie bestsellers: de Adagia (1500), het Handboekje (1503) en de Lof der zotheid (1511). De adagia zal ik hier verder niet bespreken; het is een verzameling spreuken en citaten; hoewel Erasmus vaak uitgebreide voetnoten en toelichtingen geeft, kunnen wij hier niet spreken van een oorspronkelijk theologisch werk. Het succes van het Handboekje voor de militante christen was niet zo groot als dat van de Adagia, maar het was er wel degelijk (Huizinga 1936:58). Gedurende Erasmus' leven werd de Latijnse tekst meer dan vijftig maal herdrukt (O'Donnell 1981:xiv); daarnaast verschenen vertalingen in het Engels, Duits, Tsjechisch, Spaans, Nederlands en Pools (Dolan 1964:24). Dit is een uitgesproken vroom boek in de traditie van de de Broeders des gemenen levens, bij wie Erasmus een deel van zijn opleiding had genoten, in de traditie ook van Thomas à Kempis en diens Navolging van Christus. Verschil met de Navolging is dat dat werk door de eeuwen heen populair is gebleven, terwijl het Handboekje van Erasmus in vergetelheid is geraakt. Dat komt wellicht doordat Erasmus later zowel in RoomsKatholieke als in protestantse kring verdacht werd; in Rooms-Katholieke kring vooral omdat hij zo lang wachtte met zijn reactie op Luther, en in protestantse kring vanwege de inhoud van die reactie. De Sorbonne veroordeelde in 1526 zelfs enkele stellingen uit het Handboekje (Dolan 1964:25; Huizinga 1936:171) en uiteindelijk wordt Erasmus niet vanwege zijn vroomheid of rechtzinnigheid herdacht, maar vanwege zijn geleerdheid. De Lof der zotheid is verreweg het meest succesvolle boekje van de drie; sinds het in 1511 voor het eerst verscheen, is het steeds weer en in talloze talen herdrukt, en dat tot op de dag van vandaag. Al met al waren Erasmus' geschriften in zijn eigen tijd zo populair, dat in de jaren dertig van de zestiende eeuw tussen de tien en twintig procent van alle verkochte boeken op zijn naam stond (Galli \& Olsen 2000:343). Tijdens zijn leven werden er 300.000 exemplaren van zijn Griekse Nieuwe Testament verkocht, 750.000 exemplaren van andere boeken (Johnson 1976:Ch.5).

Erasmus kan derhalve zonder overdrijving één van de eerste bestsellerauteurs worden genoemd. Opmerkelijk is vervolgens dat deze theoloog primair als eminent wetenschapper wordt herinnerd; ook op gebieden waar hij zich bij uitstek als gelovige heeft uitgesproken, wordt hij toch vooral als wetenschapper herdacht. Het feit dat hij zich als gelovige uitsprak, werd kennelijk op geen enkele wijze ervaren als strijdig met zijn wetenschappelijke integriteit. Dat geldt bijvoorbeeld voor de bijbelwetenschap (Krans 2006). Erasmus had een broertje dood aan exegeten die bleef hangen een puur wetenschappelijke benadering van de letterlijke betekenis van Bijbelteksten en daarbij de geestelijke betekenis volstrekt uit het oog verloren:

Ik zou aanbevelen dat je vooral die commentatoren leest die zo ver mogelijk van de letterlijke betekenis afwijken. Degenen die ik het sterkst zou aanbevelen zijn naast Paulus Origenes, Ambrosius, Hiëronymus en Augustinus. Te veel van onze moderne theologen neigen tot een letterlijke interpretatie, die onbedoeld misleidend is. Zij delven niet tot in de mysteriën, alsof Paulus niet de waarheid sprak toen hij zei dat onze wet een geestelijke is. Sommige van deze theologen zijn zo onder de indruk van deze menselijke commentatorendat zij wat oude uitleggers te zeggen hadden, naar het dromenrijk verwijzen. $^{18}$

18 Vrije vertaling van: 'Ex interpretibus diuinae scripturae eos potissimum delige, qui a littera quammaxime 
Deze woorden hebben nog niets van hun actualiteit verloren en hadden evengoed geschreven kunnen zijn met veel hedendaagse wetenschappelijke exegese in gedachten. Filologischhistorische benaderingen zijn zinvol, maar als zij worden verabsoluteerd gaat alle aandacht naar taal en cultuur en verdwijnt de boodschap van de tekst uit beeld.

In onze tijd is de vroomheid van Erasmus enigszins op de achtergrond geraakt. Wij lezen vooral de Lof der zotheid, en daaruit dan de satirische passages over theologie, monniken en geestelijkheid. Toen ik de Lof der zotheid enkele jaren geleden voor het eerst helemaal las, viel mijn mond dan ook open. Dit was een ander boek dan dat waarvan ik de inhoud dacht te kennen. Huizinga heeft opgemerkt: 'Voor de tijdgenoten heeft de betekenis der Laus Stulitiae voor een niet gering deel in de directe satire gelegen' (Huizinga 1936:79.) Ik denk dat dat niet alleen voor de tijdgenoten van Erasmus gold, maar ook voor latere generaties. Een populaire inleiding in Erasmus vat zijn intentie in de Lof der zotheid als volgt samen: 'De ware wijsheid is voor Erasmus in laatste instantie niets anders dan het evenwicht dat elk fatsoenlijk mens moet bewaren tussen zijn hart en zijn verstand en iedere verstoring van deze harmonie is in zijn ogen verwant aan dwaasheid' (Van Damme 1960:114). In talloze karakteriseringen van de Lof der zotheid wordt wel kort vermeld dat ook het geloof in de sfeer van de dwaasheid wordt getrokken (Degroote 1971:170), maar daar wordt het ook bij gelaten. Huizinga peilt dieper, wanneer hij stelt:

Door het gehele werk heen klinken voortdurend twee thema's door elkaar: dat van de heilzame dwaasheid, die de ware wijsheid is, en dat van de gewaande wijsheid, die louter dwaasheid is. ... Nu is het duidelijk, dat het hoofdthema in het eerstgenoemde ligt. Daarvan gaat Erasmus uit, daarheen keert hij terug. Slechts in het middengedeelte, der revue der menschelijke kundigheden en waardigheden in hun algemene dwaasheid, neemt het tweede thema de overhand, en wordt het geschrift een gewone satire op de menschelijke dwaasheid (Huizinga 1936:78-79).

Voor Huizinga is het hoofdthema van dit werk derhalve de heilzame dwaasheid die de ware wijsheid is. Maar hoewel het woord 'heilzaam' hier verrassend trefzeker gekozen is, zoekt men bij Huizinga tevergeefs naar een nadere invulling van dit heil.

Dat zou er mee te maken kunnen hebben dat Huizinga geen antenne heeft voor de religieuze kant van Erasmus. Maar het zou er ook mee te maken kunnen hebben dat Huizinga dit werk van Erasmus te veel als een tussendoortje ziet, een amuse geschreven tijdens enkele dagen van ziekte. Daarmee tuint Huizinga dan met open ogen in de literaire fictie die Erasmus zo zorgvuldig heeft geconstrueerd. Met open ogen, want Huizinga lijkt zich er goed van bewust dat de kleinerende wijze waarop Erasmus steeds over de Lof der zotheid heeft gesproken, als bedoeling had, zijn critici de wind uit de zeilen te nemen (Huizinga 1936:81-82). Hij doorziet echter niet (Huizinga 1936:73-74), dat ook de fabel dat het werk in slechts enkele dagen tot stand kwam, deel is van deze strategie. M. A. Screech heeft laten zien, dat het boekje dat in eerste druk werd gepubliceerd in Parijs in 1511, immens verschilt van de editie uit 1516 die wij kennen uit onze vertalingen. Wat weinig mensen zich realiseren, is dat Erasmus aan het boekje is blijven werken. In 1511 telde het nog slechts 48 blz., en het is duidelijk dat Erasmus tussen 1511 en 1514 (toen

recedunt. Cuiusmodi sunt in primis post Paulum Origenes, Ambrosius, Hieronymus, Augustinus. Video enim neotericos theologos litterae nimium libenter inhaerere et captiosis quibusdam argutiis magis quam eruendis mysteriis operam dare, quasi uero non uere dixerit Paulus legem nostram spiritualem esse. Audiui ego nonnullos, qui sibi usque adeo humanis illis commentatiunculis placebant, ut ueterum interpretamenta paene pro somniis contemnerent.' Erasmus, Enchiridion militis christiani 2 (http:// www.intratext.com/IXT/LAT1000/ P3.HTM). Vgl. Voor Erasmus' Schriftopvatting De Maeseneer 1963:84-107; Kohls 1966:126-143, 182;. Aldridge 1966; Hofmann 1994. 
in Straatsburg in editie verscheen die al veel leek op de latere in Basel gedrukte editie) nog heel veel aan het boek heeft geschaafd en toegevoegd. Wij moeten derhalve concluderen dat Erasmus jaren heeft gewerkt aan het boek zoals wij dat kennen. Het is een voldragen werk van Erasmus op het toppunt van zijn kunnen; in 1516 was hij in de tweede helft van de veertig (Screech 1980:xix-xx).

De belangrijkste reden echter dat de diepere religieuze dimensies van de Lof der zotheid tot voor kort niet werden opgemerkt, is dat dit niet paste in het gangbrae beeld van het ontstaan van de Reformatie. In dat beeld ontstond de Reformatie omdat de Rooms-Katholieke Kerk diep in verval verkeerde en had Erasmus daarbij een dubbele rol. Enerzijds bereidde hij de Reformatie voor met zijn teksteditie van het Nieuwe Testament en zijn kritische studies van de kerkvaders. Anderzijds bereidde hij de Reformatie voor met zijn satirische kritiek op de kerk van zijn dagen. Erasmus wordt zo gezien als wegbereider van de Reformatie, niet als geleerde met een eigen agenda. Zijn opbouwend-vrome werk past niet in de beeld; dat geldt zowel voor het Enchiridion als voor het slot van de Lof der zotheid, waarin Erasmus naar eigen zeggen niets anders wilde doen dan in een ander register nog een keer herhalen wat hij in het Enchiridion al had gezegd (Screecln zijn Enchiridion geeft Erasmus tweeëntwintig algemene regels voor een waarlijk christelijk leven (regulae generales veri Christianismi). Uit deze regels blijkt, hoe christocentrisch de vroomheid van Erasmus is. Het gaat hierom, dat wij Christus voor ons plaatsen als het enige doel van ons leven, dat wij al ons streven, al onze pogingen, onze vrije tijd zowel als ons werk uitsluitend en alleen op Hem richten (regel 4). Onze enige toegang tot Christus is het geloof, en daarom moeten wij het grootste vertrouwen op de Schrift hebben (regel 1). Nergens leren wij meer over Jezus dan in de Evangeliën (regel 5); er staat niets in de Schrift dat niet tot ons heil dient (regel 1). Heel ons leven moeten wij in dit licht beoordelen: het gaat erom dat wij meer en meer één worden met Christus (Erasmus 1905: vgl. Weiler 1997:18-20).

Wie eerst het Enchiridion leest, vervolgens De lof der zotheid, ontdekt dat de overeenkomsten inderdaad zeer groot zijn. In twee opzichten vindt in de Lof der zotheid echter een radicalisering plaats. Eerstens heeft vooral het middendeel van de Lof der zotheid het karakter van een Luciaanse satire. ${ }^{19}$ Praktijken die in het Enchiridion onder kritiek worden gesteld, worden hier ronduit belachelijk gemaakt. Dit geldt bijvoorbeeld voor allerhande devoties. In het Enchiridion stelt Erasmus dat mensen die voordeel verwachten van een reliek van het heilig Kruis in hun huis, er beter aan zouden doen het mysterie van het kruis voortdurend voor ogen te houden (Erasmus 1905:157). In de Lof der zotheid neemt Erasmus allerlei devoties als bijgeloof op de korrel en steekt er ongezouten de draak mee. De gewoonte om heiligen om voorspraak te vragen en daarbij aan elke heilige zijn eigen invloedssfeer toe te kennen (zodat wij juist Antonius moeten aanroepen om verloren voorwerpen terug te vinden), kan bij hem slechts op hoon rekenen. Dat neemt niet weg dat Erasmus wel plek heeft voor de heiligen: als wij van hun voorbeeld leren hoe Christus na te volgen in onze eigen tijd, dan is dat prima (Erasmus 1947:79-83)! Kortom, Erasmus' kritiek op wat hij afwijst wordt bijtender, maar zijn boodschap blijft ongewijzigd. Het tweede opzicht waarin Erasmus' boodschap in de Lof der zotheid wordt geradicaliseerd is dat in de Lof der zotheid wanneer het om navolging gaat, het Kruis van Christus nog centraler staat dan in het Enchiridion. Paulus spreekt in zijn brieven diverse keren over de dwaasheid van het Kruis, en Erasmus citeert hem:

De boodschap over het kruis is dwaasheid voor wie verloren gaan, maar voor ons die

19 Lucianus (ca. 120-180) was in de vroege Renaissance de meest gedrukte Griekse schrijver. Hij was Erasmus' favoriete auteur uit de oudheid. Erasmus vertaalde zijn werk en werd diepgaand door hem beïnvloed, wat vooral tot uitdrukking komt in de Lof der zotheid en de Colloquia familiaria. Zie Veenman 1999. 
worden gered is het de kracht van God. Er staat namelijk geschreven: "Ik zal de wijsheid van de wijzen vernietigen, het verstand van de verstandigen zal ik tenietdoen." [...] Want zoals God in zijn wijsheid bepaalde, heeft de wereld hem niet door haar wijsheid gekend, en hij heeft besloten hen die geloven te redden door de dwaasheid van onze verkondiging. De Joden vragen om wonderen en de Grieken zoeken wijsheid, maar wij verkondigen een gekruisigde Christus, voor Joden aanstootgevend en voor heidenen dwaas. Maar voor wie geroepen zijn, zowel Joden als Grieken, is Christus Gods kracht en wijsheid, want het dwaze van God is wijzer dan mensen [...]. Denk eens aan uw roeping, broeders en zusters. Onder $u$ waren er niet veel die naar menselijke maatstaf wijs waren [...]. Maar wat in de ogen van de wereld dwaas is, heeft God uitgekozen om de wijzen te beschamen [...]. Zo kan geen mens zich tegenover God op iets beroemen. Door hem bent u één met Christus Jezus, die dankzij God onze wijsheid is geworden. Door Christus worden wij rechtvaardig en heilig en door hem worden wij verlost. (1 Cor. 1: 18-30) ${ }^{20}$

Het staurocentrisme van de Lof der zotheid lijkt dus te verklaren vanuit de Paulijnse link tussen Kruis en dwaasheid. Erasmus werkt in de slotbladzijden van zijn Lof der zotheid vervolgens naar een climax toe, waarin hij niet alleen het kruis waarmee Christus voor ons het heil heeft verworven als een vorm van dwaasheid typeert, maar ook het geloof waarmee wij dat heil accepteren en dat heil zelf. Ook dat zijn voor hem vormen van dwaasheid. Wanneer er in het evangelie staat "Ik dank U, Vader, [...] dat Gij deze dingen voor wijzen en verstandigen verborgen hebt, doch aan kinderkens geopenbaard" (Mt. 11:25; cf. Lc. 10:21), dan wil Erasmus het nèpioi dat in de hier weergegeven NBG51-vertaling met "kinderkens" is vertaald, met "dwazen" (stulti) vertalen. Het Griekse nèpios betekent letterlijk "niet-sprekend"; kleine kinderen spreken nog niet. Vandaar kan het overdrachtelijk ook "dwazen, idioten" betekenen; de overeenkomst is natuurlijk gebaseerd op het feit dat die ook niet spreken. Erasmus prefereerde deze vertaling vanwege het contrast met de "wijzen en verstandigen". ${ }^{21}$ Gelovigen zijn geen wijzen en verstandigen, maar dwazen. Zelfs het heil waarnaar zij streven is een vorm van dwaasheid. En opnieuw speelt Erasmus dan met de verbinding tussen gekte en niet kunnen spreken: de mystieke extase die een voorproefje is van het hemels geluk, is ineffabilis, onuitsprekelijk; in deze extase geraakt de mens buiten zichzelf en wanneer hij weer tot zichzelf is gekomen, weet hij niet waar hij geweest is en wat hij gehoord of gezien heeft. Daarom kan hij er ook niet over spreken. Toch zouden zij, die een dergelijke ervaring hebben meegemaakt, niets liever willen dan op deze wijze eeuwig waanzinnig zijn, ook al is dit maar een klein voorproefje van hun toekomstig geluk (Erasmus 1947:164-166).

Zo is het slot van de Lof der zotheid tevens de climax: een beschrijving van de hoogste dwaasheid, dat wil zeggen de mystieke extase als voorproefje van het eeuwig hemels geluk.

\section{SAMENVATTING EN CONCLUSIES}

In het voorgaande heb ik stilgestaan bij de aard en de status van de confessionele theologie. Ik heb

20 Een reeks citaten uit deze tekst treft men bij Erasmus 1947:152-154.

21 Erasmus 1947:154. Screech 1980:30-33: Erasmus vertaalde daadwerkelijk met stulti in de eerste editie van zijn Novum instrumentum, maar haalde later contre coeur bakzijl voor de scherpe kritiek die hij op dit punt ontving. Hij wijzigde zijn vertaling, maar in commentaren en parafrases handhaafde hij zijn standpunt. De NBV kiest nu niet voor de 'letterlijke' vertaling met 'kinderen,' maar voor de vertaling 'eenvoudige mensen.' Die vertaling is misleidend, omdat 'eenvoud' ook een morele betekenis kan hebben: bij eenvoudige mensen denk je al gauw aan eerlijke en onschuldige mensen in tegenstelling tot sluwe, berekenende en schijnheilige mensen. Die morele lading is hier duidelijk niet bedoeld; het gaat hier niet om mensen die onschuldig als kinderen zijn, maar om mensen die zelf nog niet kunnen denken of spreken. 
betoogd dat nu het zwaartepunt van theologische Nederland verschuift van de Rijksuniveriteiten naar confessionele instellingen, het tijd is voor een nieuw elan van de confessionele theologie. Ik heb betoogd dat onze cultuur theologie nodig heeft; zowel de moderne natuurwetenschap als onze moraal zijn diepgaand verbonden met de theologie. Waar theologisch denken wordt vervangen door "zomaar-denken" (de wereld is zomaar onstaan, onze moraal is zomaar ontstaan), ontstaat er een intellectueel en moreel vacuüm dat in een handomdraai opnieuw gevuld is, maar dan nu op een manier die wij niet alleen afwijzen maar waar wij ook geen weerwoord meer tegen hebben. Juist het besef dat wij geen weerwoord hebben, leidt tot de xenofobe reacties op de islam, reacties die veel sterker zijn dan men op grond van de feiten over de opkomst van de islam zou verwachten. Die feiten vallen immers nogal mee.

Vervolgens ben ik ingegaan op de kritiek die je vaak hoort dat theologie, en met name confessionele theologie, onvrij, heteronoom, en daarmee onwetenschappelijk zou zijn. Voorzover theologie binnen de grenzen van een bepaalde confessie of belijdenis moet blijven, zo heet het dan, is theologie heteronoom en onvrij, en daarmee ook geen wetenschap. Ik heb deze kritiek besproken aan de hand van een adagium waarmee confessionele theologie nogal eens geassocieerd wordt: Lex orandi, lex credendi. Volgens een gangbare interpretatie betekent dit dat de wet van het gebed, ofwel de liturgische praktijk van de kerk, bron en norm van de theologie is. $\mathrm{k}$ heb laten zien dat de kerkvader op wie dit adagium teruggaat er een heel andere bedoeling mee had, namelijk: als wij de opdracht hebben om te bidden voor de bekering van mensen, dan moet die bekering uiteindelijk ook van God afhankelijk zijn. Deze uitspraak was bovendien niet als algemeen adagium bedoeld, maar had zijn plaats in een discussie met Semipelagianen. Natuurlijk kan men bij dit specifieke Schriftberoep ook de vraag naar heteronomie stellen, maar wij hebben gezien dat hier geen sprake is van intellectuele heteronomie: Prosper beroept zich wel op de Schrift, maar dat betekent geenszins dat met hem niet wetenschappelijk over de betekenis van Schriftpassages te discussiëren valt. Integendeel, op een dergelijke wetenschappelijke discussie is hij juist uit.

Nadat ik op deze wijze de wetenschappelijkheid van confessionele theologie tegen één belangrijke tegenwerping heb verdedigd, keerde ik terug naar de relevantie van theologie, en dat deed ik aan de hand van Erasmus. Erasmus is in onze tijd in bredere kring vooral bekend als wetenschapper en satiricus. Van zijn theologisch werk is vooral zijn aanval op Luther nog altijd bekend, en dat dan vooral in protestantse kring. Dat Erasmus ook een constructief theoloog was met grote aandacht voor het geestelijk leven, blijkt zowel uit het Enchiridion als uit het slotdeel van de Lof der zotheid. Zelfs de satirische passages uit zijn Lof der zotheid blijken geïnspireerd op zijn visie op wat een waarlijk christelijk leven was: hij drijft de spot met het tegendeel. Ik heb al gezegd dat ik meen dat de confessionele theologie in onze tijd voor belangrijke opdrachten staat. Kan zij bij het vervullen van die opdrachten nog iets leren van Erasmus? In welke opzichten kan Erasmus ook voor ons nog een voorbeeld zijn?

Erasmus hanteerde de hoogste wetenschappelijke standaards. Zijn statuur als intellectueel was onomstreden; hij hoefde in het wetenschappelijk debat in niemand zijn meerdere te erkennen. Dit is ook nu voor de theologie van groot belang: dat theologen intellectuelen zijn die op grond van hun wetenschappelijk werk ook buiten eigen kring gezag hebben.

Erasmus was priester en rooms-katholiek theoloog; toch zal niemand gedacht hebben dat hij een soort buikspreker van de Paus was. Hij combineerde trouw aan de traditie waaruit hij voortkwam en aan de christelijke geloofsbelijdenis met een grote vrijmoedigheid om binnen die traditie misstanden aan de orde te stellen. Ik ben mij er van bewust dat er op specifieke punten kritiek op Erasmus mogelijk is, maar toch denk ik dat theologie die in onze tijd een verschil wil maken, iets soortgelijks zal moeten doen: enerzijds vasthouden aan de eigen traditie en belijdenis en anderzijds met vrijmoedigheid kritiek leveren waar daar aanleiding toe is, binnen en buiten de eigen traditie. 
Erasmus speelt op de bal, niet op de man. In de inleiding op de Lof der zotheid beklemtoont hij dat hij bewust de namen van zijn tegenstanders niet noemt (Erasmus 1947:16); hij is niet op ketterjacht. Ook hier kunnen hedendaagse theologen nog veel van Erasmus leren, niet alleen waar het gaat om het respectvol benaderen van collega's met een andere opvatting, maar ook waar het gaat om het respectvol beoordelen van collega's met een andere opvatting. Te veel theologen kunnen alleen kwaliteit ontdekken in onderzoeksvoorstellen waar zij inhoudelijk sympathie voor hebben. In een tijd waarin een groot deel van het wetenschappelijk onderzoek op projectbasis wordt gefinancierd, waarbij de oordelen van wetenschappelijke peers doorslaggevend zijn, keert dit zich tegen de theologie: als een goed voorstel door peers op oneigenlijke gronden negatief wordt beoordeeld, zal de Nederlandse Organisatie voor Wetenschappelijk Onderzoek (NWO) het niet financieren. NWO moet immers afgaan op de peers.

Erasmus' theologie is niet alleen geworteld in geleerdheid, maar ook in vroomheid. En op die vroomheid is zijn denken uiteindelijk ook weer gericht - ook in de Lof der zotheid, en dat nog wel heel expliciet. Dat lijkt mij ook voor de hedendaagse theologie van belang: dat zij geen louter academische discipline wordt, maar geworteld blijft in het geloofsleven van een gemeenschap, en daarop ook blijft gericht.

\section{BIBLIOGRAFIE}

Aldridge, John W. 1966. The Hermeneutics of Erasmus. Winterthur: P.G. Keller.

Augustijn, Cornelis 1962. Erasmus en de Reformatie: Een onderzoek naar de houding die Erasmus ten opzichte van de Reformatie heeft aangenomen. Amsterdam: H.J. Paris.

Brümmer, Vincent 1985. Wat doen wij als wij bidden? Een studie in de wijsgerige theologie. Kampen: Kok Agora.

Brümmer, Vincent 1988. Over een persoonlijke God gesproken: Studies in de wijsgerige theologie. Kampen: Kok Agora.

Brümmer, Vincent 1993. Liefde van God en mens. Kampen: Kok, 1993.

Cohen, H.F. 2011. How Modern Science Came into the World. Amsterdam: Amsterdam University Press.

De Clerck, Paul 1994. "'Lex orandi, lex credendi': The Original Sense and Historical Avatars of an Equivocal Adage'", Studia Liturgica 24, 178-200.

Degroote, Gilbert 1971."Van de 'Lof der zotheid' tot de 'Samenspraken,'” in: C. Augustijn e.a., Erasmus. Hasselt: Heideland-Orbis, 165-184.

De Letter, P. (ed.) 1963. Prosper of Aquitaine: Defense of St. Augustine. NY: Newman Press.

DeCoursey, Matthew 1966. "Erasmus and Tyndale on Bible-Reading", Reformation 1, 157-164, op internet: http://www.tyndale.org/Reformation/1/decoursey.html (bezocht 16 juli 2012).

De Maeseneer, F. 1963. De methode van de theologie volgens Erasmus. Rome?: Bibliotheca Alfonsiana.

Dolan, John P. 1964. The Essential Erasmus. NY: The American Library.

Ebeling, Gerhard 1979. Dogmatik des christlichen Glaubens, I. Tübingen: Mohr.

Erasmus, Desiderius 1905. A Book Called in Latin Enchiridion Militis Christiani, and in English the Manual of the Christian Knight. London: Methuen; op internet: http://ebooks.library.ualberta.ca/local/ bookcalledinlati00erasuoft (bezocht 5 oktober 2012).

Erasmus, Desiderius ${ }^{11} 1947$. De lof der zotheid vert. J.B. Kan. Amsterdam: Wereldbibliotheek.

Erasmus, Desiderius 1981. Enchiridion Militis Christiani: An English Version ed. by Anne M. O’Donnell. Oxford: OUP.

Galli, Mark \& Ted Olsen 2000. 131 Christians Everyone Should Know. Nashville: Holman Reference.

Hofmann, Manfred 1994. Rhetoric and Theology: The Hermeneutic of Erasmus. Toronto: University of Toronto Press.

Hooykaas, Reijer 1972. Religion and the Rise of Modern Science. Grand Rapids, MI: Eerdmans.

Huizinga, Johan ${ }^{3} 1936$. Erasmus. Haarlem: Tjeenk Willink.

Hwang, Alexander Y. 2009. Intrepid Lover of Perfect Grace: The Life and Thought of Prosper of Aquitaine.

Washington, DC: Catholic University of America Press.

Johnson, Paul 1976. A History of Christianity. NY: Atheneum, geraadpleegd via http://krotov.info/ 
history/00/posnov/johnson_06.htm, 16 juli 2012.

Kant, Immanuel 1988. Wat is Verlichting? Ingeleid, vertaald en geannoteerd door Prof.dr. B. Delfgaauw. Kampen: Kok.

Klinker-De Klerck, Myriam 2011. Als vrouwen het Woord doen: Over Schriftgezag, hermeneutiek en het waarom van de apostolische instructie aan vrouwen. Barneveld: De Vuurbaak.

Kohls, Ernst-Wilhelm 1966. Die Theologie des Erasmus Bd. I. Basel: Friedrich Reinhardt Verlag.

Krans, Jan 2006. Beyond What is Written: Erasmus and Beza as Conjectural Critics of the New Testament. Leiden: Brill.

McAllister, James 2012. "Verklarende kracht van religieuze kennis". Lezing op Boeksymposium Herman Philipse God in the Age of Science? Utrecht, Descartes Centre, 27 april 2012.

McGrath, Alister E. 1994. Christian Theology: An Introduction. Oxford: Blackwell.

O'Donnell, Anne M. 1981. 'Introduction,' in: Erasmus 1981, xiv-liii.

Philipse, Herman 1996. "De teugelloosheid van de theologie" NRCHandelsblad 4 januari 1996, http:// vorige.nrc.nl/redactie/Web/Opinie/1995007/16.html (bezocht 5 juni 2012).

Pius XII 1947. Mediator Dei. Rome: Vaticaan.

Sarot, Marcel 2006. De goddeloosheid van de wetenschap. Zoetermeer: Meinema.

Sauter, Gerhard 1981. "Reden von Gott im Gebet", in: Bernhard Casper (Hg.), Gott nennen: Phänomenologische Zugänge. München: K. Alber, 219-241.

Screech, M.A. 1980. Ecstasy and the Praise of Folly. London: Duckworth.

Te Velde, Dolf 2010. Paths beyond Tracing out: The Connection of Method and Content in the Doctrine of God, Examined in Reformed Orthodoxy, Karl Barth, and the Utrecht School. Delft: Eburon.

Tinteroff, Natacha-Ingrid 2012. "Why I'm an Anglican and I Believe I Shall Remain so", http://www. stbonifacetrust.org.uk/documents/20120511 winning essay.pdf (bezocht 18 september 2012).

Van Rossum, Maarten 2010. Waarom is de burger boos? Amsterdam: Nieuw Amsterdam.

Van Slyke, Daniel G. 2004. 'Lex orandi lex credendi: Liturgy as Locus Theologicus in the Fifth Century?', Josephinum 11, 130-151, http://www.pcj.edu/journal/essays/vanslyke11-2.htm\#12 (bezocht 13 juli 2012).

Van Damme, Daniel 1960. Erasmus. Utrecht: Spectrum.

Veenman, René 1999 . "Van schoolvoorbeeld tot atheïst: Lucianus in de Nederlanden tot 1700", De zeventiende eeuw 15, 175-195.

Von der Dunk, H.W. 1994. “Geschiedenis en Wetenschap”, in: P.B. Cliteur, H.D. Papma \& R.T.P. Wiche (red.), Overtuigend bewijs: Over het wetenschappelijke van de niet-exacte wetenschappen. Amsterdam: Boom, 1994, 38-64.

Waddell, James Alan 2009a. "Rethinking Lex Orandi Lex Credendi", http://lexcredendilexorandi.wordpress. com/2009/05/22/hello-world/ (bezocht 27 september 2012).

Waddell, James Alan 2009b. "Lex Orandi Lex Credendi as a Theological Locus of Lutheran Liturgy", http:// lexcredendilexorandi.wordpress.com/2009/05/22/lex-orandi-lex-credendi-as-a-theologicallocus-for-lutheran-liturgy/ (bezocht 27 september 2012)

Wainwright, Geoffrey 1980. Doxology: The Praise of God in Worship, Doctrine and Life. London: Epworth Press.

Wainwright, Geoffrey 2003. "Systematische-theologische Grundlegung”, in: Hans-Christoph SchmidtLauber (Hg.), Handbuch Der Liturgik: Liturgiewissenschaft in Theologie und Praxis der Kirche. Göttingen: Vandenhoeck und Ruprecht), 72-94.

Weiler, Anton G. 1997. De spiritualiteit van Erasmus christen-humanist. Nijmegen: Valkhof Press; op internet: http://www.titusbrandsmainstituut.nl/PDF/4\%20Uitgaven/Titus\%20Brandsma\%20 Lezing\%201997\%20-\%20Weiler-Spiritualiteit.pdf, bezocht 5 oktober 2012.

Wendel, François 1950. Calvin: Sources et Évolution de sa Pensée Religieuse. Paris: Presses Universitaires de France.

\section{KEY WORDS}

Nature and function of theology

Public function

Erasmus

Prosper of Aquitaine

Autonomy 


\section{TREFWOORDE}

aard en status van teologie

publieke funksie

Erasmus

Prosper van Aquitanië

autonomie

Marcel Sarot

Professor of Fundamental Theology

Tilburg School of Catholic Theology | Tilburg University | P.O. Box 80.101 | 3508 TC Utrecht

M.Sarot@uvt.nl | tel. +31 134663839 